\title{
Effect of Competitive Strategies on Firm Performance and Mediating Role of Product Innovation
}

\author{
Funda Kılıç ${ }^{1}$ \\ ${ }^{1}$ Independent Researcher, Istanbul, Turkey \\ Correspondence: Dr. Funda Kılıç, Independent Researcher, Turkey. E-mail: fundaklc75@gmail.com \\ Received: January 10, 2022 \\ Accepted: February 4, 2022 \\ Online Published: February 17, 2022 \\ doi:10.5539/ijbm.v17n3p93 \\ URL: https://doi.org/10.5539/ijbm.v17n3p93
}

\begin{abstract}
The aim of the study is to investigate the effect of competition strategies and product innovation on firm performance and to examine the mediating role of product innovation in relation between competitive strategies and firm performance. One of quantitative methods questionnaire technique was used to test the proposed theoretical model. The research sample 225 enterprises which was listed in Istanbul Chamber of Industry (ISO) The data collection process was completed in June-July-August 2021. In this study, data were collected by questionnaire method. The obtained data were analyzed using regression analysis. The hypothesis that the idea of competitive strategies affects firm performance level was tested with simple linear regression and it was found that the hypothesis was significantly supported. According to the regression results are examined, in simple regression models in which competitive strategies and product innovation are the independent variables and firm performance is the dependent variable, it is seen that competitive strategies $(\beta=0.654 ; \mathrm{t}=16.543)$ and product innovation $(\beta=0.632 ; \mathrm{t}=8.043)$ have been seen that it has a positive and statistically significant effect on performance. Thus, in the multiple regression model product innovation variable has mediating role, between competitive strategies and firm performance. In addition, as for relationship of firm performance with the sub factors of competitive strategies, the correlation is found to be the highest between focus strategy and firm performance.
\end{abstract}

Keywords: competitive strategies, firm performance, product innovation

\section{Introduction}

Today, with the effect of globalization, the intensity of competition has increased rapidly and businesses have implemented some competitive strategies in order to gain competitive advantage. Competitive strategy is a set of decisions that describe how the business will address customers, whether it will target a particular or all of the market in which it operates, and what methods it will use to compete with its competitors. According to Porter, the presence of new entrants to the sector in which a business operates can cause a negative effect on profitability by causing current prices to decrease. In this case, the costs that businesses have to bear increase. Porter suggests that there are five forces that affect competition in the industry (Ülgen \& Mirze, 2018). Five power models that determine competition; the intensity of competition among competitors in the sector consists of the bargaining power of customers, the bargaining power of suppliers, the threat of substitute goods and services, and the threat of new entrants to the market (Koçoğlu \& Kantar, 2016). Porter suggested cost leadership, differentiation and focus strategies to combat the five forces he identified.

Innovation is considered as the main element of competitive power spread over an area creating a new form of organizational structures, processes, products and services. Innovation uses technology as a means of competition, and technological competition also manifests itself as the driving force of growth. Entering new markets, existing basic growth strategies to increase market share and provide a competitive advantage to the business considered as one of its components. Therefore, innovation is an indispensable element for more efficient production the implementation of corporate strategies for various purposes such as implementing processes and performing better. Innovation helps businesses overcome the problems they face and serve as a strategic guide as we seek to maintain a sustainable competitive advantage.

This study explores the effect of competition strategies and product innovation on firm performance and to examine the mediating role of product innovation in relation between competitive strategies and firm performance. Although there are many studies in the literature the relation between competitive strategies and firm performance, 
the studies on how product innovation of companies effects on firm performance by this variable are limited. This study will fill this gap in the literature, as well as draw attention to the mediating role of product innovation on the relation between competitive strategies and firm performance. In the theoretical framework part, the variables competitive strategies; cost strategy, differentiation strategy, focus strategy, product innovation and firm performance that are the subject of the research are defined. The hypotheses created to test the relationships between the variables are presented in the research model. In the methodology part, the research sample and the measurement scales are clarified. In the conclusion part, the relationship between the variables are discussed and for future studies and limitations of the study are mentioned.

\section{Literature Review}

\subsection{Competitive Strategies}

Porter (1980) identified three key strategies for companies to achieve better firm performance. In these three basic strategies called cost, differentiation and focus. With this approach, Porter made a significant contribution to making strategy an easier and more understandable concrete concept by removing it from an abstract concept. He concretely defined not only the concept, but also the "environment" factor, which significantly affects the concept. By shaping many factors that are ambiguous when it comes to the company and the environment, he clarified a field that was actually blurred for the second time, by stating that there are five forces when it comes to the company's environment: the power of suppliers, the power of competitors in the industry, the power of possible competitors, the power of buyers, the power of substitute goods.

Cost leadership strategy is the generic strategy that aims to be the least costly manufacturer in the market (Gopalakrishna \& Subramanian, 2001). The basis of the cost leadership strategy, without neglecting quality, service and other areas have a lower cost compared to competitors. Coming to this position allows the company to earn a return above the sectoral average, even when the competition is very intense. Having a low cost gives the firm a strong position against its competitors and protects the firm against strong buyers. Businesses that adopt the cost leadership strategy generally engage in activities for the standard customer group of their target market and for the needs that are not classified as specialty goods/services (Kaya, 2013). Businesses that adopt this strategy tend towards practices that will reduce not only certain items but also all costs of the business (Dinçer, 2013). Businesses that adopt the differentiation strategy try to gain competitive advantage by making the goods or services offered to their customers different from the goods or services offered by their competitors. For this purpose; efforts are made to differentiate elements such as the design of the product, the brand value created, the technology used or offered, after-sales services, and distribution channels. The differentiation strategy is based on offering a unique product and design, brand, technological features and customer service (Yamin, Gunasekaran, Mavondo, \& Sarros, 1997). Differentiation strategy, on the other hand, is a strategy designed to attract customers who have a special interest in the features of certain products, and trying to create customer loyalty by emphasizing the features that distinguish their products from similar ones. The implementation of this strategy depends on the effectiveness of the companies in their marketing activities, brand promotion efforts, quality management and strong corporate image. Due to the position they have in the market, businesses that are successful in the differentiation strategy can both expand their loyal customer portfolio, increase their profitability by applying higher prices in the pricing policies of their products and services, and become more advantageous in scaling compared to their competitors (Lumpkin and Dess, 2006). Businesses that adopt the focus strategy apply derivatives of cost leadership and differentiation strategies to customers in the target market they have determined. This method is generally preferred by businesses who think that they cannot exist in a fierce competition environment (Duman, Özpeynirci, Yücenurşen, \& Apak, 2014). Businesses that implement the focus strategy aim to provide services to niche regions in order to meet the needs of customers who have stock or service problems, or to meet the demands of small or medium-sized customer groups for specific products (Barca, 2020).

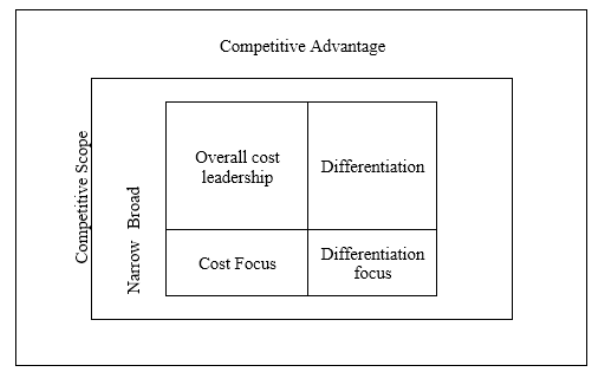

Figure 1. Porter's generic strategies for competitive advantage 
Source: Porter, M. (1985).

\subsection{Firm Performance}

Firm performance refers to the strategies implemented by the firm as a result of a certain period, the degree of achievement of its goals in outputs and practices, in other words, the level of success of the firm (Porter, 1991). On the other hand, there is no clear definition of concept. According to Hsu and Jang (2007) financial performance includes some sub-dimensions such as sales of new products, profitability, capital employed and return on assets (ROA). According to Grossman (2000) return on investment (ROI), earnings per share (EPS) and net income after tax (NIAT) can also be used as measures of financial performance. In other study by Richard, Devinney, Yip and Johnson (2009) organizational performance encompasses three dimensions: financial performance, product market performance and shareholder return. However, Selvarajan, Ramamoorthy, Flood, Guthrie, MacCurtain, and Liu (2007) claimed that firm performance can also be measured using perceived performance approach measuring quality, employee satisfaction and overall firm performance. This study focus on the following eleven firm performance outcomes;

- Qualified labor

- Commitment of employees

- Job satisfaction of employees

- New product/service development capability

- Product/service quality

- Customer satisfaction

- Sales growth

- Market share growth

- Return on sales

- Return on assets

- Overall profitability

Qualified labor is the sum of using physical and mental effort in production of goods and services. The benefits of having the trained employees using the most advanced technology may be overridden by employees who do not use their effort for the utility of the company. Meyer, Allen and Gellatly (1990), defines commitment is "a psychological state that binds the individual to the organization". In today's competitor world, no organization can perform at the highest level unless each employee is committed to the organization's goals and works as an effective team member. Job satisfaction is crucial for organizations concerned with developing and retaining productive employees for organizational success (Siegel \& Lane, 1974). Locke (1976) defines job satisfaction as "a pleasurable and positive emotional state caused by the appraisal of one's job or job experience". The ability to develop new product/service is the process of transforming knowledge and ideas into better ways of doing business or improved products and services valued by society. Product/service quality is the added value customers receive when they purchase the product or service. Customer satisfaction refers to degree of which a product or service meets the customer's expectations. Sales growth is the increase in sales over a specific period of time. Market share growth is the percentage of the total sales of a particular type of product or service attributable to a particular firm. Return on sales is a measure of a company's profitability, equal to a fiscal year's pre-tax income divided by total sales. Return on assets (ROA) is an indicator of how profitable a company is relative to its total assets. Overall profitability is company's ability to generate revenues in excess of the costs incurred in producing those revenues.

\subsection{Product Innovation}

In the competitive environment of today's rapidly developing and globalizing markets, organizations are struggling to become a little more advantageous compared to their competitors. They constantly differentiate their products, services or management processes in competition and they need to be renewed and replaced. This renewal, differentiation and change activities are called innovation. In other words, innovation; distribution to a good or service for the purpose of bringing an idea to market (Elçi, 2006). Scholars doing research on innovation have generally advocated two different views. Some scholars consider the concept of innovation according to which conditions it emerges: structural or conceptual. Another part considers innovation as a process how emerges, develops and makes it a routine part of organizational activities (Damanpour \& Gopalakrishnan, 1998). According to OECD (1995) innovation can be found in internal practices, workplace organization or external a new or significantly improved product, service or process, a new marketing method or organizational management success. 
The word innovation was first used by Schumpeter (1911) defined as "the driving force of development". Firms that implement an innovation strategy will also be successful if their innovations are successful and they are more likely to be competitive in terms of cost, performance, product marketing and development compared to other noncompeting firms in a market (Lindgren \& Abdullah, 2013). As in figure 2. the aim of the study is to investigate the effect of competition strategies and product innovation on firm performance and to examine the mediating role of product innovation in relation between two variables.

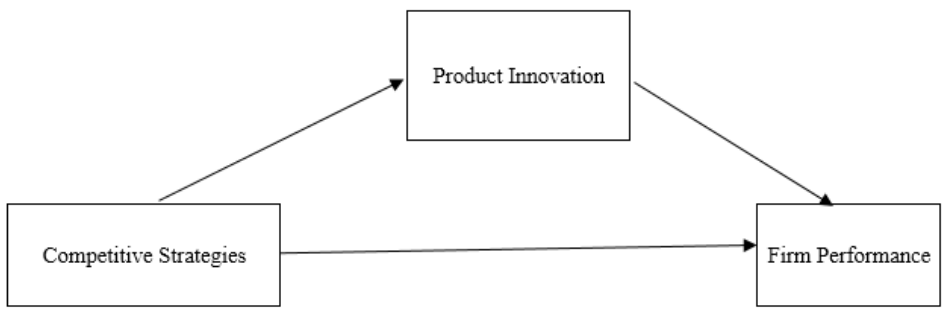

Figure 2. Research model

As seen in Figure 2, competition primarily The effects of strategies on firm performance will be examined. Subsequently, the impact of competitive strategies on product innovation will be examined. Then, the effect of product innovation on firm performance effect will be considered. Finally, as seen in the research model, the effect of competitive strategies on firm performance and the mediating role of product innovation will be examined.

H1: Competitive strategies have a statistically significant effect on product innovation.

H2: Competitive strategies have a statistically significant effect on firm performance.

H3: Product innovation has a statistically significant effect on firm performance.

H4: Product innovation has a mediating effect on the effect of competitive strategies on firm performance

\section{Research Methodology}

The research universe encompassed Istanbul Chamber of Industry (ISO) list as a total of 1000 enterprises, the top 500 and the second 500 published each year (https://www.iso500.org.tr/about-iso-500/history-and-methodology/) Among these enterprises, 300 enterprises with at least 50 employees were selected in Istanbul. One of quantitative methods questionnaire technique was used to test the proposed theoretical model. The data collection process was completed in June-July-August 2021. The Generic Strategies Scale questionnaire was sent to the top executives of the determined businesses. The Generic Strategy Scale was developed by Yamin et al. (1999). The scale consists of a total of 27 statements: 12 statements for the differentiation strategy, 10 statements for low cost leadership, 5 statements for the focus strategy. According to previous studies on this scale, results on the value of Kaiser-MeyerOlkin (KMO) was greater than 0.70, the data is suitable for factor analysis; Bartlett value,000 indicates that significant factors will emerge from the data (Peker, Özdemir, Kerse, \& Arsu, 2016, Leech, Barrett and Morgan, 2005). The statements in the original scale were arranged on a 5-point Likert scale. While making the evaluation, the statements were changed from "strongly disagree" to "strongly disagree" rated as "I agree". For measuring firm performance; the nine performance indicators were adapted from Barringer and Bluedorn (1999), and Wiklund and Shepherd (2003). Respondents were asked to compare with a competitor of their own firm over recently years, using five-point scales anchored at low to high. The reported reliabilities and validities of the measures reported in the literature were: coefficient alphas of all constructs exceed the 0.70 level and all EFA factor loadings 0.40 . A seven-point, multi-item Likert-type scale to measure the product innovation, and the construct was defined as unidimensional and latent. The scale was referred to the OCDE (2005) Oslo Manual to generate the five reflective items, the reported reliabilities and validities of the measures in the literature were supported (Camison \& Lopez, 2010).

The responses from the questionnaires have been analyzed with statistical techniques. SPSS program was used for the analysis. In order to obtain meaningful findings from the collected data, first of all, the reliability and validity of the measurements of the variables were confirmed. For this purpose, the scales, whose validity was tested before, were reduced to sub-factors with Exploratory Factor Analysis (EFA) and made ready for other analyses. Afterwards, hypotheses were tested with regression analysis and significant differences in results were noted with nonparametric tests.

The companies responded with a 75\% return rate, 225 white-collar employees answered the relevant questionnaire. $39 \%$ of the managers who answered the questionnaire are in top management level, $45 \%$ of companies have 
between 50 and 100 employees, $40 \%$ of the companies in automotive sector.

Table 1. Demographic variables

\begin{tabular}{|c|c|c|c|c|}
\hline $\mathrm{N}=215$ & & Frequency & $\%$ & Cumulative $\%$ \\
\hline \multirow[t]{2}{*}{ Gender } & Female & 101 & 45 & \\
\hline & Male & 124 & 55 & \\
\hline \multicolumn{5}{|l|}{ Position } \\
\hline & Top Level Management & 88 & 39 & 64 \\
\hline & Middle Level Management & 78 & 35 & 74 \\
\hline & Low Level Management & 59 & 26 & 100 \\
\hline \multicolumn{5}{|c|}{ The Number of Employees } \\
\hline & $50-100$ & 100 & 45 & 45 \\
\hline & $101-200$ & 70 & 31 & 76 \\
\hline & $201-300$ & 28 & 13 & 88 \\
\hline & $301-400$ & 16 & 7 & 95 \\
\hline & $500-+$ & 11 & 5 & 100 \\
\hline \multicolumn{5}{|l|}{ Sector } \\
\hline & Manufacturer & 27 & 12 & 1 \\
\hline & Automotive & 90 & 40 & 41 \\
\hline & Chemical Industry & 68 & 30 & 71 \\
\hline & Service & 65 & 29 & 100 \\
\hline
\end{tabular}

\section{Results and Discussion}

According to results of analysis the Cronbach Alpha reliability coefficient of the scales used in the study was $86.4 \%$ for competitive strategies, $85.7 \%$ for firm performance and $83.3 \%$ for product innovation. Based on these data, it can be argued that the reliability coefficients are high for all scales used in the study.

Table 2. Cronbach's Alpha scores of instruments

\begin{tabular}{lll}
\hline Instrument & The Number of Items & Cronbach's Alpha (\%) \\
\hline Generic Strategy Scale & 27 & 0,864 \\
Firm Performance Scale & 9 & 0,857 \\
Product Innovation Scale & 5 & 0,833 \\
\hline
\end{tabular}

As a result of the factor analysis for the items of the competitive strategies scale, which is the independent variable of the research model, the KMO value was found to be 0.920 after some iteration. Two items were taken out because they were having similar factor loadings under different factors. In the final factor analysis, the measured variable revealed three meaningful factors: cost strategy, differentiation strategy and focus strategy.

According to the result of the Bartlett Sphericity test for the data group was found to be $\mathrm{p}<.001$, which means that there is a significant relationship between the items of the scale. Therefore, it is understood that this scale is suitable for factor analysis and that the measured feature is multidimensional in the universe from which the sample was selected $(X 2=4991.327 ; \mathrm{SD}=135)$. These factors explain $77 \%$ of the variable variance in total. Considering that the variance rates ranging from $40-60 \%$ are considered ideal in social sciences (Çokluk, Şekercioğlu and Büyüköztürk, 2010: 36), it can be said that the $77 \%$ variance rate obtained as a result of this research is quite satisfactory. It shows that the reliability of the items constituting three factors is quite high ( $\alpha \operatorname{cost}$ strategy $=0.863$; $\alpha$ differentiation strategy $=0.823$; $\alpha$ focus strategy $=0.833$ ). Explained variance by cost strategy is $31.98 \%$ variance by differentiation strategy is $27.23 \%$, and variance by focus strategy is $20.72 \%$, in total, they explain $79.93 \%$ of the variance.

The second independent variable, product innovation, was found to have a KMO value of 0.81 as a result of EFA after a few iterations. $(\mathrm{X} 2=3155.783$; $\mathrm{sd}=137 \mathrm{ve} \mathrm{p}<0,001)$. As a result of the factor analysis, the variable revealed 
one factors. This factor explains $67.17 \%$ of the total variance of the variable. Reliability analyzes of the factor was performed and the internal consistency coefficients of factor was found sufficient to continue the analysis (aproduct innovation $=0.833$ ).

The dependent variable, firm performance, was found to have a KMO value of 0.85 as a result of EFA after a few iterations. $(\mathrm{X} 2=3274.793$; $\mathrm{sd}=132 \mathrm{ve} \mathrm{p}<0,001)$. As a result of the factor analysis, the variable revealed two factors: qualitative performance and quantitative performance. These two factors explain $65.17 \%$ of the total variance of the variable. Reliability analyzes of the two factors were performed and the internal consistency coefficients of all factors were found sufficient to continue the analysis (aquantitative performance $=0.853$; aqualitative performance $=0.864$ ).

The amount of correlation between the dependent and independent variables is determined to be $\mathrm{r}=0.687$ in nonparametric correlation analysis, which is considered a moderate association. As for relationship of firm performance with the sub factors of competitive strategies, the correlation is found to be the highest between focus strategy and firm performance $(\mathrm{r}=0.642)$. This correlation is at strong level. Accordingly, it can be said that product innovation is highly correlated with focus strategy $(\mathrm{r}=0.713)$.

Table 3. Correlation analysis

\begin{tabular}{llllll}
\hline & 1 & 2 & 3 & 4 & 5 \\
\hline 1. Cost Strategy & 1 & & & & \\
2. Differentiation Strategy &, $667^{* *}$ & 1 & & & \\
3. Focus Strategy &, $732^{* *}$ &, $637^{* *}$ & 1 & & \\
4. Product Innovation &, $636^{* *}$ &, $675^{* *}$ &, $713^{* *}$ & 1 & \\
5. Firm Performance &, $613^{* *}$ &, $622^{* *}$ &, $642^{* *}$ &, $712^{* *}$ & 1 \\
\hline
\end{tabular}

Note. $* *$ Correlation is significant at the 0,01 level (2-tailed).

Regression analysis was used since the study hypotheses included assumptions for investigating causal linkages. Multiple regression analysis was used since the independent variable included two sub components. To analyze the links between variables and their sub-factors, correlation analysis between variables must be performed first. The Kolmogorov-Smirnov test was used to determine if the variables had a normal distribution before doing the correlation analysis.

Table 4. Regression analyses

\begin{tabular}{|c|c|c|c|c|}
\hline \multicolumn{5}{|c|}{ Dependent variable: Firm Performance } \\
\hline & Variables & Beta & $\mathrm{t}$ & $\mathrm{p}$ \\
\hline \multicolumn{5}{|l|}{ Model 1} \\
\hline & Competitive Strategies & 0.654 & 16.543 & 0.000 \\
\hline \multicolumn{5}{|c|}{$\mathrm{R}=0.674 ; \mathrm{R}^{2}=0.470 ; \mathrm{F}=275.418 ; \mathrm{p}=0.000$} \\
\hline \multicolumn{5}{|l|}{ Model 2} \\
\hline & Product Innovation & 0.632 & 8.043 & 0.000 \\
\hline \multicolumn{5}{|c|}{$\mathrm{R}=0.712 ; \mathrm{R}^{2}=0.515 ; \mathrm{F}=151.436 ; \mathrm{p}=0.000$} \\
\hline \multicolumn{5}{|c|}{ Dependent variable: Product Innovation } \\
\hline & Variables & Beta & $\mathrm{t}$ & $\mathrm{p}$ \\
\hline \multicolumn{5}{|l|}{ Model 3} \\
\hline & Firm Performance & 0.659 & 7.143 & 0.000 \\
\hline
\end{tabular}

Notes. $\mathrm{R}=0.631 ; \mathrm{R}^{2}=0.424 ; \mathrm{F}=112.551 ; \mathrm{p}=0.000$.

Both the dependent and independent variables were fully engaged in the regression analysis for hypothesis testing. Simple regression analysis was used since the first hypothesis primarily assumes the effect of competitive 
strategies on firm performance. As it is seen in Table 4., the hypothesis that the idea of competitive strategies affects firm performance level was tested with simple linear regression and it was found that the hypothesis was significantly supported $(\beta=0.654 ; \mathrm{p}<0.05)$; (Model 1). Accordingly, the competitive strategies to explain firm performance is $\mathrm{R}^{2}=0.47$ which means that; competitive strategies explain $47 \%$ variance of firm performance. The hypothesis that the product innovation affects firm performance level was tested with simple linear regression and it was found that the hypothesis was significantly supported $(\beta=0.712 ; p<0.05)$; (Model 2$)$. Accordingly, the competitive strategies to explain firm performance is $\mathrm{R}^{2}=0.71$ which means that; competitive strategies explain $51 \%$ variance of firm performance. The hypothesis that the product innovation affects firm performance level was tested with simple linear regression and it was found that the hypothesis was significantly supported $(\beta=0.631$; $\mathrm{p}<0.05$ ); (Model 3). Accordingly, the competitive strategies to explain firm performance is $\mathrm{R}^{2}=0.71$ which means that; competitive strategies explain $42 \%$ variance of firm performance. Table 5. presents the results of the multiple regression analysis examining the effects of competitive strategies and product innovation scales on firm performance. When Table. 4 is examined, it was determined that the independent variable competitive strategies $(\beta=0.435 ; \mathrm{t}=6.747)$ and product innovation $(\beta=0.423 ; \mathrm{t}=7.883)$ dependent variable had a positive and statistically significant effect on firm performance.

Table 5. Multiple regression analyses

\begin{tabular}{|c|c|c|c|c|}
\hline \multicolumn{5}{|l|}{ Dependent variable: Firm Performance } \\
\hline & Competitive & 0.435 & 6.747 & 0.000 \\
\hline & Strategies & & & \\
\hline & Innovation & & & \\
\hline
\end{tabular}

Notes. $\mathrm{R}=0.504 ; \mathrm{R}^{2}=0.270 ; \mathrm{F}=115.413 ; \mathrm{p}=0.000$.

According to the regression results are examined, in simple regression models in which competitive strategies and product innovation are the independent variables and firm performance is the dependent variable, it is seen that competitive strategies $(\beta=0.654 ; \mathrm{t}=16.543)$ and product innovation $(\beta=0.632 ; \mathrm{t}=8.043)$ have been seen that it has a positive and statistically significant effect on performance. Thus, in the multiple regression model (Table.4), in which the effects of competitive strategies and product innovation on firm performance are examined together, both variable, the effect on firm performance is positive and was found to be statistically significant as in Figure 3.

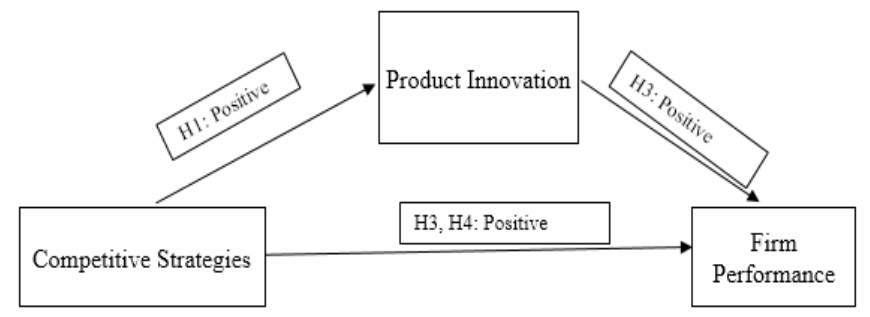

Figure 3. Research model based on hypothesis accepted or rejected

\section{Conclusion}

The purpose of this study is to examine the effect of competition strategies and product innovation on firm performance and to examine the mediating role of product innovation in relation between competitive strategies and firm performance. For the advanced analysis, the acquired data was compared to the factors indicated in earlier research in the literature and those discovered in this one. The sub hypotheses could thus be examined using factor analysis. Finally, the variables were looked at to see whether there were any significant differences between the sample groups. After regression analysis, the study's hypothesis was confirmed. According to the regression results are examined, in simple regression models in which competitive strategies and product innovation are the independent variables and firm performance is the dependent variable, it is seen that competitive strategies 
$(\beta=0.654 ; \mathrm{t}=16.543)$ and product innovation $(\beta=0.632 ; \mathrm{t}=8.043)$ have been seen that it has a positive and statistically significant effect on performance.

According to the findings obtained in line with the purpose of the study, competition strategies and product innovation have a positive impact on firm performance. When the effect of scales on firm performance is examined, differentiation strategy, cost strategy and focus strategy had significantly positive effect on firm performance. In addition, as for relationship of firm performance with the sub factors of competitive strategies, the correlation is found to be the highest between focus strategy and firm performance $(r=0.642)$. In the study conducted by Kamaşak (2010) on 157 businesses, it was determined that businesses that apply both differentiation and low-cost leadership strategies together are more successful in terms of profitability and market performance than those that do not apply either strategy successfully. Peker, Özdemir, Kerse and Arsu (2016) on businesses operating in Aksaray Organized Industrial Zone, it was found that cost leadership strategy affects customer-oriented performance, sales and profitability-oriented performance, while differentiation strategy strongly affects customer-oriented performance and product-oriented performance. It was determined that it did not affect the performance. It has been determined that the focus strategy only affects the product-oriented performance. In the research conducted in companies that dominate the market in online commerce such as Amazon, E-bay and Google, it has been found that generic strategies are positively related to firm performance, but the differentiation strategy is more sustainable in the online market than the low cost leadership strategy (Suleman, Rashidirad, \& Suleman, 2019).

Companies would differentiate their products and services in a way that would either make their customers pay more money or provide the lowest costs in the industry, and they would do one of these two strategies by focusing on either broad markets or narrow markets we call niches. Innovation provides businesses with a competitive advantage and increases their profits and being a powerful weapon in increasing the market (Zerenler, Türker, \& Esen, 2006) Because it is related to the innovation power of enterprises (Oflazoğlu \& Koçak, 2012) innovations are very important for the long-term performance of enterprises. OECD (2005) defines innovation that activities, any type of technology that drives new or improved products or processes and also improves firm performance. Bulut, Yilmaz, \& Alpkan (2009) stated that risk orientation and value orientation have positive effects on firm innovation performance and value orientation has positive effects on firm financial performance. In his study, Eren (2013) stated that proactive orientation and innovation, which are the entrepreneurial marketing dimension, have a positive effect on the financial performance of the firm. According to Terzioğlu and Topuz (2020) when entrepreneurial marketing is included in the model in which the effect of competitive strategies on firm performance is examined, it was seen that the coefficients decreased, but were significant according to the regression analysis. Based on this information, it has been determined that entrepreneurial marketing has a partial mediation effect on the relationship between competitive strategies and firm performance. According to Erdem, Gül, and Gül (2013) findings, it was detected that market orientation and innovation orientation have significant and positive oriented relations with firm performance. Camison and Lopez's (2010) research that studied the relationship between manufacturing flexibility and firm performance; the mediating role of innovation, has found that the effect on organizational performance of adopting a flexible productive system is mediated by incorporating product, process, and organizational innovation. Although there are many studies on innovation and firm performance in the strategic management literature which are given in literature and conclusion part, there are limited studies on how product innovation affects the relationship between firm performance according to which strategy within the scope of competitive strategies. Therefore, this study fills an important gap.

For future research different variables may be included in the relationship of competitive strategies and firm performance. Firm performance, which refers to the strategies implemented by the firm as a result of a certain period, the degree of achievement of its goals in outputs and practices, in other words, the level of success of the firm (Porter, 1991), has had an impact on all levels of society and has altered how we do business. In the work environment after Pandemy, competitive strategies has brought both obstacles and opportunity. The possibility of digital transformation, the quality of product and services, the risk of even greater economic inequality, and so on are all concerns across the world.

This study has some limitations. The research was examined in different corporate firms and data was conducted by qualitative methods. The sample size of data is one of the limitations in this research. As a result of qualitative method, the outcomes are limited. For future studies both qualitative and quantitative methods can be used in order to decrease the constraints.

\section{References}

Barca, M., Pearce, J. A., Robinson, R. B. (2020). Stratejik yönetim: Geliştirme, uygulama ve kontrol.

Bulut, Ç., Yılmaz, C., \& Alpkan, L. (2009). Pazar oryantasyonu boyutlarının firma performansına etkileri. Ege 
Akademik Baklş Dergisi, 9(2), 513-538.

Camisón, C., \& López, A. V. (2010). An examination of the relationship between manufacturing flexibility and firm performance: The mediating role of innovation. International Journal of Operations \& Production Management, 30(8), 853-878.

Damanpour, F., \& Gopalakrıshnan, S. (1998). Theories of organizational structure and innovation adoption: The role of environmental change. Journal of Engineering Technology Management, 15, 1-24.

Dinçer, Ö. (2013). Stratejik Yönetim ve İşletme Politikası (9th ed.). İstanbul, Alfa Yayım.

Duman, H., Özpeynirci, R., Yücenurşen, M., \& Apak, İ. (2014). Girişimcilik açısından Porter'nn jenerik (rekabet) stratejileri ve işletme performansına etkisi. ICE 14 VI International Congress on Entrepreneurship, 515-522.

Elçi, Ş. (2006). İnovasyon Kalkınmanın ve Rekabetin Anahtarı. İstanbul, Pelit Yayınları.

Erdem, B., Gül, K., \& Gül, M. (2013). Pazar yönlülük, inovasyon yönlülük ve firma performansı ilişkisi: Ankara'da faaliyet gösteren dört ve beş yıldızlı otel işletmelerinde bir araştırma. İşletme Araştırmaları Dergisi, 5(2), 74104.

Eren, S. (2013). Girişimsel pazarlamanın firmaların finansal performansına etkisi. Dumlupınar Üniversitesi Sosyal Bilimler Dergisi, 35, 97-106.

Gopalakrishna, P., \& Subramanian, R (2001). Revisiting the pure versus hybrid dilemma: Porter's generic strategies in a developing economy. Journal of Global Marketing, 15, 61-79. https://doi.org/10.1300/J042v15n02_04

Grossman, R. J. (2000). Measuring up: Appropriate metrics help HR prove its worth. HR Magazine, 45(1), 28-35.

Hsu, L. T., \& Jang, S. (2007). The postmerger financial performance of hotel companies. Journal of Hospitality \& Tourism Research, 31(4), 471-485.

Kamaşak, R. (2010). Jenerik rekabet stratejilerinin işletme karlılığı ve pazar performansına etkisi, Yönetim Dergisi: İstanbul Üniversitesi İsletme İktisadı Enstitüsü, 21(65), 47-64.

Kaya, N. (2013). Küçük ve orta büyüklükteki işletmelerde (KOBI) stratejik yönetim. Ankara, Detay Yayıncılık.

Koçoğlu, D., \& Kantar, M. (2016). Türkiye madencilik sektörünün beş güç modeli ile değerlendirilmesi, İşletme ve Bilişim Yönetimi Dergisi, 3(1), 2-3.

Leech, N. L., Barrett, K. C., \& Morgan, G. A. (2005). SPSS for intermediate statistics: Use and interpretation. New Jersey: Lawrence Erlbaum Associates.

Lindgren, P., \& Abdullah A. M. (2013). Conceptualizing strategic business model innovation leadership for business survival and business model innovation excellence. Journal of Multi Business Model Innovation and Technology, 115-134.

Locke, E. A. (1976). The nature and causes of job satisfaction. In Dunnette, M. D. (Ed.), Handbook of Industrial and Organizational Psychology (pp. 1297-349).

Meyer, J. P., Allen, N. J., \& Gellatly, I. R. (1990). Affective and continuance commitment to the organization: Evaluation of measures and analysis of concurrent and time-lagged relations. Journal of Applied Psychology, 75(6), 710. https://doi.org/10.1037/0021-9010.75.6.710

OECD - Oslo Manual. (2005). Proposed guidelines for collecting and interpreting technological innovation data (2nd ed.).

Oflazoğlu, S., \& Koçak, A. (2012). Stratejik yönlülüklerin yenilik ve performans üzerindeki etkisi. Çankırı Karatekin Üniversitesi İktisadi ve İdari Bilimler Fakültesi Dergisi, 2(1), 121-144.

Peker, A. A., Özdemir, Ş., Kerse, G., \& Arsu, T. (2016). Porter'ın jenerik rekabet stratejileri ve performans ilişkisi: Aksaray ili organize sanayi bölgesi örneği. Manas Sosyal Araştırmalar Dergisi, 5(5), 11-23.

Porter, M. E. (1980). Competitive strategy techniques for analyzing industries and competitors. Free Press.

Porter, M. E. (1991). Towards a dynamic theory of strategy. Strategic Management Journal, 12, 95-117. http://dx.doi.org/10.1002/smj.4250121008

Richard, P. J., Devinney, T. M., Yip, G. S., \& Johnson, G. (2009). Measuring organizational performance: Towards methodological best practice. Journal of Management, 35(3), 718-804. https://doi.org/10.1177/0149206308330560

Selvarajan, T. T., Ramamoorthy, N., Flood, P. C., Guthrie, J. P., MacCurtain, S., \& Liu, W. (2007). The role of human 
capital philosophy in promoting firm innovativeness and performance: Test of a causal model. The International Journal of Human Resource Management, 18(8), 1456-1470. https://doi.org/10.1080/09585190701502588

Siegel, L., \& Lane, I. M. (1974). Psychology in industrial organizations. McGraw-Hill/Irwin.

Suleman, M. F., Rashidirad, M., \& Suleman, S. F. (2019). The applicability of Porter's generic strategies in pure online firms: A case study approach. Strategic Change. https://doi.org/10.1002/jsc.2258

Terzioğlu, E., \& Topuz, Y. V. (2020). Rekabet stratejilerinin firma performansına etkisi ve girişimsel pazarlamanın aracilık rolü: Bir örnek uygulama. Bolu Abant İzzet Baysal Üniversitesi Sosyal Bilimler Enstitüsü Dergisi, 20(1), 147-167. https://doi.org/10.11616/basbed.v20i53206.641374

Ülgen, H., \& Mirze, K. (2018). İsletmelerde stratejik yönetim (9th ed.). İstanbul, Beta Basın Yayın Dağıtım

Yamin, S., Gunasekaran, A., Mavondo, F., \& Sarros, J. (1997). A study of competitive strategy, organisational innovation and organisational performance among Australian manufacturing companies. International Journal Production Economics, 52, 161-172.

Zerenler, M., Türker, N., \& Esen, Ş. (2006). Küresel teknoloji, araştırma-geliştirme (Ar-Ge) ve yenilik ilişkisi. Selçuk Üniversitesi Sosyal Bilimler Enstitüsü Dergisi, 17, 653-667.

\section{Copyrights}

Copyright for this article is retained by the author(s), with first publication rights granted to the journal.

This is an open-access article distributed under the terms and conditions of the Creative Commons Attribution license (http://creativecommons.org/licenses/by/4.0/). 